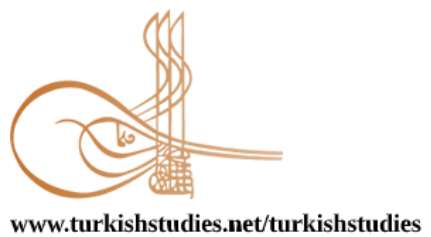

Turkish Studies

www.turkishstudies.net/turkishstudies

eISSN: $1308-2140$

Research Article / Araștırma Makalesi

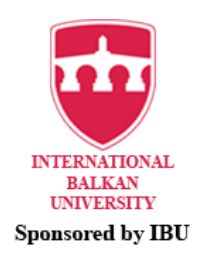

\title{
Yaşlı Ayrımcılığının Pandemi Hali: COVID-19 Sürecinde Kuşaklararası Etkileşimin Dönüşümü
}

\author{
Pandemic State of Ageism: Transformation of Intergenerational Interaction During COVID-19 \\ Pandemic
}

\author{
Berfin Varışl1 ${ }^{*}$ - Tule Gültekin ${ }^{* *}$
}

\begin{abstract}
The COVID-19 crisis has caused global economic, cultural and social change by affecting many areas in society, from the way individuals interact to daily practices. Social isolation, started with curfew restrictions taken to prevent the spread of the COVID-19 virus, changed the course of everyday life and led to changes and transformations in the nature of many institutions within the social structure. These changes and transformations in the public and private sphere also reshaped the order of intergenerational interactions. The percentage of COVID-19 related deaths among individuals above 65 years of age is significantly higher compared to other age groups. This occasion sets the scene that the most disadvantageous group of age are the elder individuals. The elder individuals who already confront problems such as exclusion, poverty, loneliness and discrimination before COVID-19 have been marginalized and exposed to much more severe and violent discriminatory attitudes and behaviours by other members of the society through the medium of social and physical isolation. These attitudes and behaviours reinforce and reproduce ageism by covering discoursive and non-discoursive practices. In this context, this study aims to address the effect of curfew restrictions that are applied on elderly people in Turkey on intergenerational interactions and ageism. To achieve this goal, an analysis is made on the basis of the triangle of power, domination and discourse, using the perspectives of Foucault and Bourdieu.
\end{abstract}

Structured Abstract: The increase in the elderly population in Turkey has also increased the importance of examining the effect of the pandemic on the lives of older individuals. In Turkey, where almost one in 10 people is 65 years of age or older, it is clear that the pandemic is causing a change in intergenerational interaction. On the other hand, it should be noted that how elderly individuals are affected by the pandemic process depends on many factors such as their social positioning, roles and life arrangements.

Curfew restrictions that are applied to elderly individuals in Turkey, based on chronological age, have closed them inside the households, caused them to enter into a kind of social isolation. Although these measures were taken to protect them from the virus, this caused them to move away from their social environment for

\footnotetext{
* Dr. Öğretim Üyesi, Maltepe Üniversitesi, İnsan ve Toplum Bilimleri Fakültesi, Sosyoloji (İngilizce) Bölümü Assistant Professor, Maltepe University, Faculty of Humanities and Social Sciences, Department of Sociology (English) ORCID 0000-0001-5051-9546

berfinvarisli@maltepe.edu.tr

*** Arş. Gör., İstanbul Üniversitesi-Cerrahpaşa, Sağlık Bilimleri Fakültesi, Gerontoloji Bölümü

Research Assistant, Istanbul University - Cerrahpaşa, Faculty of Health Science, Department of Gerontology

ORCID 0000-0002-9531-7187

tulegultekin@istanbul.edu.tr

Cite as/ Atıf: Varışl1, B., Gültekin, T. (2020). Yaşlı ayrımcılığının pandemi hali: COVID-19 sürecinde kuşaklararası etkileşimin dönüşümü. Turkish Studies, 15(4), 1227-1237. https://dx.doi.org/10.7827/TurkishStudies.44376

Received/Geliș: 20 June/Haziran 2020

Accepted/Kabul: 10 August/Ağustos 2020

Checked by plagiarism software

Copyright $(\mathcal{C}$ MDE, Turkey

Published/Yayın: 30 August/Ağustos 2020

CC BY-NC 4.0
} 
some time. The sense of closure and stress caused by the fact that individuals cannot go out for days made it inevitable for tensions to arise within the family and caused intergenerational conflicts. The side that is discriminated against, despised and scorned within the intergenerational conflict is mostly elderly individuals. In this respect, the domination experienced by elderly individuals increases it's severity during a crisis period like pandemic.

It can be said that particularly elderly people living alone experience this process more painfully. According to TurkStat data, the ratio of the number of households of elderly people living alone to the number of households with at least one elderly person is $24.3 \%$ (TurkStat, 2019). The fact that elderly individuals living alone during the pandemic cannot meet their many needs due to social and physical distance, and become in need of other individuals, makes them dependent for social support by affecting them both psychologically and socially. This enables elderly individuals to interact more intergenerationally, but it can lead to conflict and breakdowns.

According to Dumas and Turner (2006) in the social sciences, there are two basic approaches that would be useful for understanding the relationship of Foucault's theory to old age and ageing. The first approach is the structuralist approach, which reads the body as a representation of the power structure, and treats it on the basis of a cultural system of meaning through discourse. The discourse, when examined within the structure of complex relations of domination, lies in the middle of this relationship and is never independent of power (Foucault, 2016: 182). The discourse is closely related to the forms of power, hierarchy and conflict, and the spread of power and the formation of discourse are connected by a strong bond (Şahin, 2017: 122).

The second approach underlined by Dumas and Turner (2006: 145) is the phenomenological approach that focuses on understanding the "lived body" experience, thus emphasizing the performance and social practices of the body. The ageing body, in other words the "lived body", has been losing it's power which was internalized through social norms and values over the years. In this sense, the domination over the bodies, which Foucault (1992) called docile bodies increases and folds as they age. Therefore, the age and the role losses that come with age, which causes the loss of power in many cases, increases the number of subjects that the obedient bodies obey and intensifies domination. The subject in question is sometimes his/her son, sometimes his/her daughter-in-law, sometimes the man on the street. In other words, elderly individuals in the public and private sphere are in a position where the ongoing domination is reproduced day by day.

According to Foucault (1993: 11), discourses contain prohibitions and contradictions in themselves. Individuals benefit from discourses when forming a chain of domination over each other. Especially in the early days of the COVID-19 outbreak, the elderly individuals were portrayed as one of the factors in the spread of the disease, rather than as those under the risk group.

Foucault, who makes the conceptualization of dangerous individuals through discipline, refers to the discipline of individuals through the justice and criminal system as the most visible form of domination (Barth, 2008: 304). In COVID-19 pandemic, elderly were positioned as a single profile by society; social and cultural differences and factors such as gender were ignored. However, the physical and emotional needs of older individuals were neglected and other age groups imposed both explicit and implicit domination on them.

Pierre Bourdieu presents a similar perspective to "lived bodies" with his concept of habitus. According to Bourdieu (1990), power is culturally and symbolically produced and continuously strengthened through the interaction of the agent and the structure. Habitus forms a basis to this fact. Bourdieu (2006: 116) defines habitus as "socialized subjectivity". The institutions internalized by the individual determine the individual's daily life practices. According to Bourdieu (2000: 152), the body is the embodiment of social structure through taste and practice. For this reason, the old age process of the individual is related to his/her habitus. His/her daily life practices, preferences and tastes in his/her youth and adulthood are also grounds for his old age experience. Social positioning is also one of the factors that produces "the lived body" and shapes the experience of old age.

Foucault and Bourdieu's approaches are useful for understanding the social positioning of the elderly individual during the pandemic period. The dominance of the pandemic over the lived body has enhanced the discrimination of people who are over the age of 65 , living both with the family and alone. As habitus shapes the process of old age, it helps to understand the power and domination over the older individual. The reproduction of ageing on the basis of habitus combined with domination and discourse, made the positioning of the elderly individual within society clearly.

Turkish Studies, 15(4) 
The death anxiety that the pandemic may have caused, coupled with intergenerational conflict, has made the situation of the elderly in the process even more negative. In the pandemic, the long coexistence of different generations in the same households has caused the consolidation of generational conflict and the increase of intergenerational distance.

Keywords: Sociology, COVID-19, Pandemic, Ageism, Foucault, Bourdieu, Domination, Discourse.

Öz: COVID-19 pandemi krizi, toplum içinde bireylerin etkileşim şekillerinden, günlük yaşam pratiklerine kadar pek çok alana etki ederek küresel anlamda ekonomik, kültürel ve sosyal değişime neden olmuştur. COVID-19 virüsünün yayılmasının önüne geçmek için alınan sokağa çıkma kısıtlama önlemleriyle başlayan sosyal izolasyon, gündelik yaşamın seyrini değiştirerek toplumsal yapı içinde birçok kurumun doğasında değişim ve dönüşü̈me yol açmıştır. Kamusal ve özel alanda meydana gelen bu değişim ve dönüşümler, kuşaklararası etkileşim düzenini de yeniden şekillendirmiştir. Diğer yaş gruplarına nazaran 65 yaş üstü bireylerin COVID-19 virüsü nedeniyle yaşamını kaybetme oranının daha yüksek olması, bu süreçten etkilenen en dezavantajlı yaş grubunun yaşlı bireyler olmasına zemin hazırlamış̧ır. COVID-19 öncesi dönemde dışlanma, yoksulluk, yalnızlık ve ayrımcılık gibi sorunlarla karşı karşıya olan yaşlı bireyler; bu süreçte sosyal ve fiziki izolasyon ile birlikte toplumun diğer fertleri tarafindan daha keskin ve şiddetli ayrımcı tutum ve davranışlara maruz bırakılıp ötekileştirilmişlerdir. Bu tutum ve davranışlar, yaşlı bireyleri topyekün tahakküm altına alan söylemsel olan ve söylemsel olmayan pratikleri kapsayarak yaşlı ayrımcılığını pekiştirmekte ve yeniden üretmektedir. Bu çerçevede bu çalışma; Türkiye'de COVID-19 pandemisi kapsamında, 65 yaş üstü bireylere yönelik kronolojik yaşı temel alarak uygulanan dışarı çıkma kısıtlamalarının kuşaklararası etkileşim ve yaşlı ayrımcılı̆̆ına etkisini Michel Foucault ve Pierre Bourdieu perspektifinden bakarak iktidar, tahakküm ve söylem üçgeni üzerinden ele almayı amaçlamaktadır.

Anahtar Kelimeler: Sosyoloji, COVID-19, Pandemi, Yaşlı Ayrımcılı̆̆ı, Foucault, Bourdieu, Tahakküm, Söylem.

\section{Giriş}

Son yılların en büyük biyopsikososyal krizi olarak karşımıza çıkan COVID-19 pandemisi küresel hareketliliği bozguna uğratarak durağanlığa ve gelecekle ilgili belirsizliğe neden olmuştur. Aralık 2019'da Çin'in Hubei eyaletinin başkenti olan Wuhan'da başlayan enfeksiyon, 11 Mart 2020'de Dünya Sağlık Örgütü tarafindan COVID-19 (SARSCoV2 Enfeksiyonu) olarak tanımlanmış ve bu tarihten itibaren pandemi ilan edilmiştir (WHO, 2020a). COVID-19 virüsü ciddi akut solunum yolu enfeksiyonlarına sebep olmakta, asemptomatik, hafif ya da şiddetli semptomatik olarak seyretmektedir (Özcan vd., 2020). Pandemi ilanı ekonomik, kültürel ve sosyal anlamda değişimin de başlangıcını oluşturmaktadır.

COVID-19'un toplumsal hayatın bütün bileşenlerine etki etmesi; bireylerin etkileşim şekillerinden, günlük yaşam alışkanlıklarına kadar pek çok noktada değişime neden olmuştur. Bu değişimin pandemi sonrası süreçte de sosyal hayatı ve sosyal ilişkileri etkilemeye devam etmesi beklenmektedir. Ne kadar süreceği belli olmayan pandemi salgını/krizi, sosyal, kültürel ve ekonomik anlamda birçok alanda da kalıcı değişim ve dönüşümlere neden olacaktır.

Genel anlamda pandeminin toplumsal etkileri ile ilgili olarak son 15 yılda pandemi döneminde sivil toplum (White \& Banda, 2009), pandemi ve kentleşme ilişkisi (Zachreson vd., 2018), pandemi ve sosyal evrim (Spinney, 2019), pandemi ve siyaset (Abumere, 2019), pandemi ve bilim (Maw, 2006; Stephens, 2005) konularında çalışmalar yapıldığ görülmektedir. COVID-19 pandemisi toplumsal yaşamı dönüştürürken sosyal bilimler literatüründe de araştırmacılar pandeminin toplumsal sonuçlarını çalışmaya başlamıştır. Pandeminin toplum genelinde artan dayanışma birliği (Choonara, 2020), toplumdaki değişim süreçleri (Singh vd., 2020) uzak ve yakın gelecekte virüsün etkileri (Tabish, 2020), klinik çalışmalardaki etkileri (Çevik vd., 2020), pandemi sırası ve sonrasında ekonomik ilişkiler (Auzan, 2020) pandemi ile ilgili belirsizlikler devam ederken 
yayımlanan çalışmalar olarak yerini almıştır. Bu makale yazılırken Türkiye'den de pek çok sosyal bilimcinin konu ile ilgili araştırmalarına devam ettikleri bilinmektedir.

COVID-19'la başlayan sosyal izolasyon, sokağa çıkma kısıtlamaları gündelik yaşamın seyrini de değiştirmekte, toplumsal yapı içinde birçok kurumun yapısında gerginliklere sebep olmaktadır. İlk kısıtlama İçişleri Bakanlığı'’nca 22 Mart 2020 tarihinden itibaren 65 yaş ve üzerindeki bireylere sokağa çıkma yasağı ile getirilmiştir. Daha sonra ise 11 Nisan 2020 tarihinden itibaren belirli aralıklarla tüm bireyleri kapsayan kısıtlamalar uygulanmıştır (İçişleri Bakanlığı, 2020). Tüm fertlerin vakitlerinin çoğunu ev içinde birbirleri ile geçirmek zorunda kalmaları, aile kurumunun yapısında ve işleyişinde de değişime yol açmış, aile içi gerginliklerin artmasına neden olmuştur. Vago (2003) yapısal gerginliklerin sosyal sistemdeki bir ya da birkaç unsurunun çatışıp karmaşa yaratması nedeniyle ortaya çıtığını ve değişime yol açtığını ileri sürer. Fertler arasında özellikle kuşaklararası etkileşimlerde ortaya çıkan bu gerginlikler de değişimin ilk halkasını oluşturmuştur. COVID-19 öncesi dönemde dışlanma, yoksulluk, yalnızlık ve ayrımcılık gibi sorunlarla karşı karşıya olan yaşlı bireyler; bu süreçte sosyal ve fiziki izolasyon ile birlikte toplum tarafından daha keskin ayrımcı tutum ve davranışlara maruz bırakılmışlardır. Öte yandan Sullivan (2009: 477)'a göre toplumsal değişme toplumun kültürü, yapısı, kurumları ve işlevi ile ilişkili geniş bir kavramdır. Dolayısıyla ailede başlayan bu gerginlik, sadece özel alanda kalmayacak kamusal alanda da kuşaklararası etkileşimin dönüşümüne neden olacak, 65 yaş üstü bireylerin maruz kaldıkları ayrımcılığı etkileyecektir. Bu çalışma Türkiye'de COVID-19 pandemisi kapsamında 65 yaş üstü bireylere yönelik kronolojik yaşı temel alarak uygulanan dışarı çıkma kısıtlamalarının yaşlı ayrımcılığına etkisini iktidar, tahakküm ve söylem üçgeni üzerinden ele almayı amaçlamaktadır.

\section{COVID-19 Pandemisi ve Türkiye'de Yaşlılık}

Türkiye'de yaşlı nüfusun artması, pandeminin yaşlı bireylerin yaşamına etkisinin irdelenmesinin önemini de artırmıştır. TÜİK verilerine göre Türkiye'de yaşlı nüfusun toplam nüfus içindeki oranı 2014 yılında \%8,0 iken 2019 yılında \%9,1'e yükselmiştir. Bu oranın 2023 'te \%10,2, 2040 'da $\% 16,3 ; 2060$ 'ta $\% 22,6$ ve 2080 'de $\% 25,6$ olacağ yanında pandeminin devam ettiği Haziran 2020'de Sağlık Bakanlığı tarafından yapılan açıklamada, son bir ayda hayatını kaybeden vatandaşların yaş ortalamasının 74,6 olduğu ve toplam ölümlerin \% 93'ünün de 65 yaş üstü olduğu bilgisi paylaşılmıştır (Türkiye'nin Koronavirüsle Mücadelesinde Son 24 Saatte Yaşananlar, Anadolu Ajans1, 06.06.2020). COVID-19 virüsünün neden olduğu ölümlerin 65 yaş ve üstü bireyler arasında bu denli fazla olması, pandemiden en çok etkilenen toplumsal grubun da yaşlı bireyler olmasına neden zemin hazırlamıştır.

Neredeyse her 10 kişiden birinin 65 yaş ve üstü olduğu ülkemizde pandeminin kuşaklararası etkileşimde değişime neden olduğu da açıktır. Öte yandan, yaşlı bireylerin pandemi sürecinden nasıl etkilendiklerinin toplumsal konumlanışları, rolleri ve yaşam aranjmanları gibi pek çok etkene bağlı olduğu da unutulmamalıdır. Pandeminin kuşaklararası etkileşimde yarattığı dönüşüm yaşlı bireyin yalnız ya da aile fertleri ve/ya yakınları ile yaşayıp yaşamaması faktörü ile de şekillenmektedir.

Aile ve/ya yakınları ile birlikte yaşayan yaşlı bireylerin hane içinde aile fertleriyle uzun süre bir arada olmaları, fertlerin günler boyunca dışarı çıkamamalarının getirdiği kapanmışlık duygusu ve stres, aile içinde gerginliklerin ortaya çıkmasını kaçınılmaz kılmış ve kuşak çatışmalarının yaşanmasına neden olmuştur. Canatan (2008: 65)'a göre kuşak çatışması "toplumun bütününü içine alan ve sonraki kuşak boyunca devamlı olan bir tür anlaşmazlıktır". Kuşaklararası çatışmada ayrımcılığa uğrayan, hor görülen ve küçümsenen taraf çoğunlukla yaşlı bireylerdir. Bir başka deyişle yaşlı bireylerin kamusal ya da özel alanda ayrımcılığa uğramaları kuşaklararası çatışmanın bir sonucudur. Bu yönüyle yaşlı bireylerin maruz kaldığı tahakküm, pandemi gibi bir kriz döneminde şiddetini arttırmaktadır. Yaşlı bireylere uygulanan, kronik yaş temel alınarak belirlenmiş sokağa çıkma kısıtlamaları onları hane içine kapatmış, bir nevi sosyal izolasyona girmelerine neden 
olmuştur. Her ne kadar bu önlemler onları virüsten korumak için alınmış olsa da bu durum onların sosyal çevrelerinden bir süre de olsa uzaklaşmalarına neden olmuştur.

Özellikle yalnız yaşayan yaşlı bireylerin bu süreci daha sancılı geçirdiği söylenebilmektedir. TÜİK verilerine bakıldığında yalnız yaşayan yaşlı bireylerin hane sayısının, en az bir yaşlı bulunan hane sayısına oranı \%24,3'tür (TÜİK, 2019). Pandemi sürecinde tek başına yaşayan yaşlı bireylerin sosyal ve fiziki mesafeden kaynaklı olarak pek çok ihtiyaçlarını karşılayamamaları, başka bireylere zorunlu olarak muhtaç duruma gelmeleri onları hem psikolojik hem de sosyal olarak etkileyerek çevresel desteğe muhtaç getirmektedir. Bu da yaşlı bireylerin daha fazla kuşaklararası etkileşime girmelerine imkân sağlamakla birlikte çatışma ve kırılmalara sebep olabilecek bir durum olarak karşımıza çıkmaktadır.

\section{Yaşlı Ayrımcılığına Foucault ve Bourdieu Perspektifinden Bakmak}

Yaşlanma sadece biyolojik bir süreç değildir, sosyal bağlamlarda gömülüdür ve sosyal faktörlerle şekillenir. Modern toplumlarda yaşlı bireyler yaşam kalitelerini yükseltmekte engellerle karşılaşabilmektedirler. Yaşlı bireylerin yaşam kalitelerini yükseltmenin önündeki en önemli engellerden biri toplumda yaşlanmaya karşı oluşan olumsuz tutum ve davranışların varlığıdır. Bu tutum ve davranışlar, bireyin yaşlarına göre klişeleştirme, önyargı ve ayrımcılık ile karakterizedir. Yaşlı bireylere, yaşlanmaya ve yaşlılığa karşı basmakalıp olumsuz tutum ve davranışlar bireyler arasındaki farklar ihmal edilmektedir. Bu olumsuz tutum, davranış, beklenti ve inançlar bireyin yaşl11ık sürecini de şekillendirmektedir. Çünkü klişeleştirici yaşç inançlar yaşlı bireyi davranılması beklendiği gibi hareket etmeye yönlendirir. Dolayısıyla, bu şekilde yaşlanma kendini yeniden üreten bir kehanet haline gelir (Ayalon \& Tesch-Römer, 2018: 1-2).

İlk olarak Robert Butler (1969: 243) tarafindan ortaya konulan yaşlı ayrımcılığı veya yaşç1lık; üç biçimde kendini göstermektedir. Bunlar (a) kendilerine ait tutumlar da dahil olmak üzere yaşlı bireylere karşı önyargı, (b) ayrımcı uygulamalar ve (c) her zaman kasıtlı olmasa da, kurumsallaşmış klişeler ve onlara zarar veren politika ve uygulamalardır.

Palmore (1999) ise yaşlı ayrımcılığını; "bir grup yaşlıya yönelik önyargı ve ayrımcılık" olarak tanımlamaktadır. Ona göre yaşlı ayrımcılı̆̆ 1 ayrıca sık sık ayrımcı eyleme çeviren inanç ve tutumları (yaşlı bireyler, çirkin, hastalıklı ve verimsiz gibi) içermektedir (Mc Mullin \& Marshall, 2001: 112).

Dünya Sağlık Örgütü’ne göre ise yaşlı ayrımc1lığ1, 65 yaş üstü bireyleri ayrımcılığa maruz bırakma, onlara önyargıyla yaklaşma olarak tanımlanmaktadır (WHO, 2020b). Nasıl kadınlar cinsiyetçiliğin bir sonucu olarak dezavantajlı konumda ise, ya da siyahilere ve diğer azınlıklara 1 rk ayrımcılığı yapılıyorsa, yaşlı bireyler de yaşçılı̆̆ın bir sonucu olarak ayrımcılığa maruz kalmaktadır (Bytheway, 2005: 361).

Öte yandan toplumlar yaşı bireylere karşı ayrımcılık yaptıklarını kabullenmeyebilir ve/ya bu davranışlarının farkında olmayabilirler. Yaşlı bireyler de, yaşlı ayrımcılığını içselleştirip, yaşçı tutum ve davranışlarda bulunabilmektedirler. Ancak şu unutulmamalıdır ki, bir toplumda ileri yaş; ölümü, değer yitimini, verimsizliği, kısıtlılığı ve anlamsızlığ hatırlatıyorsa o toplumda yaşlı bireylere karşı önyargının geliştiği söylenebilmektedir (Dean, 2009: 14).

Yaşlı bireylere karşı ayrımcı tutum ve davranışların kökenine yönelik yapılan araştırmalar pek çok farklı nedeni işaret etmektedir. Bu nedenler; yaşlı bireylerin ölüm ile eş anlamlı kavramsallaştırılmasının, politik alandan medyaya; eğitimden yönetime kadar her alanda gençlik, dinamizm, üretkenlik ve bireysellik gibi kavramların vurgulanarak toplumlarda, yaşlılığa karş1 olumsuz tutumlar geliştirilmesi (Palmore, 1999: 5-7); yaşlı bireylerin üretime katılmayan bireyler olarak görülüp gençlerin ise yaşlı bireylerin bakım ve ihtiyaçlarını karşılayan grup olarak nitelendirilmesi; onların topluma bir yük olarak düşünülmesi (Palmore, 1999: 10) ve onlarla ilgili çalışmalarda bakımevi, huzurevi gibi kurumların ön plana çıkması nedeniyle oluşan bakıma 
muhtaçlık algısı (Levy \& Banaji, 2002: 55-56) şeklinde sıralanabilir. Tüm bu bahsi geçen negatif stereotipler toplumun yaşlıya bakışını anlatır. Negatif yaşlı ayrımcılı̆̆ 1 olarak da bilinen bu stereotipler genellikle yaşlı bireylerin görünümleri ve kişiliklerini irdeleyen olumsuz inançları barındırır. Bu olumsuz inançlar yaşlı yetişkinler arasında daha düşük benlik saygısına ve kimlik kaybına yol açabilmektedir (Forlenza vd., 2019: 51). Öte yandan yaşlı ayrımcılığı her zaman olumsuz ifade ve davranışlardan oluşmaz; olumlu söylem, tutum ve ifadelerle de yaşlı bireyler ötekileştirilebilir. Cary vd. (2017) tarafından kavramsallaştırılan pozitif yaşlı ayrımcılığı "tatlı, pamuk, minnoş" gibi kulağa olumlu gelen ancak bir yetişkini betimlemekten ziyade çocuk ya da nesneleri nitelendirmek için kullanılan ifadeler ile aşırı yüksek sesle ve/ya tane tane konuşma gibi yardım olarak görünen ancak yaşlı bireyi ötekileştiren ve kötü hissetmesine neden olabilecek eylemleri içermektedir.

Yaşlı bireylere yönelik ayrımcı tutum ve davranışların öncelikli olarak sergilendiği alanları belirlemek bu sorunun önüne geçmek için gereklidir. Bu alanların başında sağlık ve sosyal bakım sektörü, emeklilik ve finans hizmetleri, kamusal alan (Bond vd., 2007: 12), aile ve hane, devlet kurumları, ücretli emek sektörü (Mc Mullin \& Marshall, 2001: 112) ve medya (Bytheway, 1995) gelmektedir. Tüm bu bahsi geçen alanlarda yaşlı ayrımcılı̆̆ı, iktidarın yaşlı tahakkümü ve yaşlı bireylere yönelik negatif söylemin vücud bulmuş hali olarak karşımıza çıkmaktadır. Burada iktidar sadece siyasi iktidar değildir. Bireylerin birbiri üzerinde kurmaya çalıştıkları iktidar/tahakküm de bu kapsamda değerlendirilmelidir. İște tam bu noktada Foucault'nun bahsettiği iktidar oluşturma arac1 olarak söylemin önemi ortaya çıkmaktadır.

Dumas ve Turner (2006)'a göre sosyal bilimlerde, Foucault'nun kuramının yaşlılık ve yaşlanma ile ilişsisini anlamak için yararlı olacak iki temel yaklaşım vardır. İlk yaklaşım, bedeni iktidar yapısının bir temsili olarak okuyan, söylem vasıtasıyla kültürel bir anlam sistemi temelinde ele alan yapısalcı yaklaşımdır. Foucault'nun oldukça önemsediği söylem sadece dilden ibaret değildir. Bir şeyleri ortaya çıkarmanın ve onları açıklamanın bütün yol ve biçimlerine söylem denir (Megill, 2012: 274). Karmaşık olan tahakküm ilişkilerinin yapısı içinde incelendiğinde söylem; bu ilişkinin tam da ortasında yer almaktadır ve asla iktidardan bağımsız değildir (Foucault, 2016: 182). Söylemler iktidar şekilleri, hiyerarşi ve çatışma olgularıyla yakından alakalıdır ve iktidarın yayılması ile söylemlerin oluşması kuvvetli bir bağ ile birbirine bağlanmıştır (Şahin, 2017: 122). Bu noktada bilgi; başkalarına yönelik tanımlar yapmaya ve iktidarı bireyler üzerinde oluşturmaya ve yeniden üretmeye imkân sağlar. Foucault'ya göre bilgi bireyin özgürleşmesinin önünde bir engeldir; bunun yanında da gözetleme ve disipline etme fonksiyonlarını da üstlenir (Sarup, 2004: 101).

Foucault'nun bahsettiği söylem yalnızca tek bir alana özgü değildir. Bireylerin yaşamlarının bütün alanlarına bireye benimsetmiş olduğu norm ve değerler yoluyla yerleşir. Bu söylemler yatay bir şekilde "iktidarı" dağıtarak kalıcı hale getirir. Söylemler tarafindan oluşturulan alanların dışına çıkmak çok zordur. Ancak yine de dışına çıkma durumunda bireylere dışlayıcı ve ayrımcı kavramlar aracılığıyla somut iktidar görünümleri kazandırılır (Foucault, 2001: 133-134).

Dumas ve Turner (2006: 145)'ın altını çizdiği ikinci yaklaşımsa "yaşanmış beden" deneyimini anlamaya odaklanmış, böylece bedenin performansına ve sosyal pratiklerine vurgu yapan fenomenolojik yaklaşımdır. Yaşlanan beden, bir başka deyişle "yaşanmış beden" yıllar boyunca toplumsal norm ve değerler vasıtasıyla içselleştirdiği iktidarı gün geçtikçe kaybetmekte ve tahakküm altına girmektedir. Bu anlamda yine Foucault (1992)'nun itaatkâr bedenler olarak adlandırdığ bedenlerin, yani bireylerin yaş aldıkça üzerlerindeki tahakküm artmakta, katlanmaktadır. Dolayısıyla yaş ve yaş ile gelen rol kayıpları, ki bu rol kayıpları pek çok örnekte iktidar kaybını da beraberinde getirmektedir, itaat eden bedenlerin itaat ettikleri öznelerin sayısını artırmakta, tahakkümü şiddetlendirmektedir. Söz konusu özne kimi zaman oğlu, kimi zaman gelini kimi zaman da sokaktaki adamdır. Bir başka deyişle kamusal ve özel alanda yaşlı bireyler, süregelen tahakkümün günden güne yeniden üretildiği bir konumdadırlar. 
Pierre Bourdieu de habitus kavramıyla "yaşanmış beden"e benzer bir bakış açısı sunmaktadır. Bourdieu (1990)'ye göre iktidar, fail ve yapının etkileşimi yoluyla kültürel ve sembolik olarak üretilir ve sürekli olarak güçlendirilir. Buna zemin hazırlayan habitustur. Bourdieu (2006: 116) habitusu "toplumsallaşmış öznellik" olarak tanımlar. Dumas ve Turner (2006: 150)'a göre Bourdieu kurumların fail olarak bireyi şekillendirmedeki rolünü kabul etmiştir. Birey tarafından içselleştirilen kurumlar, bireyin gündelik yaşam pratiklerini belirler. Bourdieu (2000: 152)'ye göre beden, beğeni ve pratik yoluyla toplumsal yapının vücut bulmuş halidir. Ayrıca beden güç ilişkilerinin ve toplumsal düzenin yeniden üretildiği bir alandır. Dolayısıyla Bourdieu perspektifinden bakıldığında "yaşanmış beden"i toplumsal olarak inşa edilen, yapının içselleştirildiği bir alan olarak yorumlamak yanlış olmayacaktır. "Yaşanmış beden" toplumsal yapı içinde şekillenen tüm yaşanmışlıkları, deneyimleri, habitus temelinde taşımaktadır. Bu nedenledir ki bireyin yaşlılık süreci onun habitusu ile bağlantılıdır. Gençliğinde ve yetişkinliğindeki gündelik yaşam pratikleri, tercihleri, beğenileri onun yaşlılık deneyimine de zemin oluşturmaktadır. Hakeza Bourdieu (2015)'nun “Ayrım”da sunduğu toplumsal tabakalaşma modeli bireyin toplumsal hiyerarşideki yerini, toplumsal konumlanışını işaret eder. Toplumsal konumlanış da "yaşanmış beden"i üreten ve yaşlılık deneyimini şekillendiren etkenlerden biridir.

Foucault ve Bourdieu'nün yaklaşımları pandemi döneminde yaşlı bireyin toplumsal konumlanışını anlamak için yararlıdır. Pandeminin yaşanmış beden üzerinde kurduğu tahakküm, gerek aile içinde gerekse yalnız yaşayan 65 yaş üstü bireylerin maruz kaldığı yaşlı ayrımcılığını katmerlendirmiştir. Habitus yaşl1lık sürecini şekillendirmesi itibariyle, yaşlı bireyin üzerindeki iktidar ve tahakkümü anlamaya yardımcı olur. Sinırlamalar, kısıtlamalar ve ölüm korkusunun neden olduğu pandemi yaşlı bireyin üzerindeki tahakkümü arttırmaktadır. Bundan yola çıkarak habitus, bireyin yaşamı ile ilgili pek çok ipucu barındırmakta ve tahakkümü ortadan kaldırmak ya da şiddetini azaltmak için alınacak önlemlere 1şık tutmaktadır.

\section{Tahakküm, Söylem ve Yaşlı Ayrımcılığı}

Belirli rutinler söylemler yoluyla normalleştirilirken, bazıları ise sapma ve/ya sapkınlık olarak adlandırılmaktadır (Layder, 2014: 142). Foucault (1993: 11)'ya göre söylem sadece bask1 sistemlerini açılayan bir şey olmamakla birlikte, onun vasıtasıyla mücadele edilen şey, ele alınmak istenen tahakküm gücüdür. $\mathrm{Bu}$ doğrultuda söylemler kendi içinde yasakları ve karşıtlıkları barındırmaktadır. Bireyler birbirleri üzerindeki tahakkümler zincirini oluştururken söylemlerden yararlanmaktadırlar. Özellikle COVID-19 sürecinin ilk günlerinde yaşıı bireyler üzerinde kurulmaya çalışılan tahakküm ve bunun aracı olan söylemlerle yaşlı bireyler risk grubu altındakiler olarak değil, hastalığın yayılmasındaki etkenlerden birisi olarak resmedilmiştir. $\mathrm{Bu}$ şekilde oluşturulan söylemlerle yaşlı bireyler ayrımcılığa maruz kalarak "tehlikeli bireyler" haline gelmiştir.

Disiplin üzerinden tehlikeli birey kavramsallaşmasını yapan Foucault, adalet ve ceza sistemi üzerinden bireylerin disipline edilmesini tahakkümün en görünür hali olarak ifade etmektedir (Barth, 2008: 304). Yaşlı bireylere yönelik uygulamaya konulan sokağa çıkma yasağı ile yaşlı bireyler için bir taraftan tehlikeli bireylermiş gibi bir algı oluşturulmaktadır. Diğer taraftan kamusal alanlar onlar için tehlikeli mekânlar olarak belirlenmiş ve mobilizasyonları sınırlandırılmış, dolayısıyla yaşlı ayrımcılığına ortam oluşturulmuştur. Yaşlı bireylere yönelik uygulamaya konulan sokağa çıkma yasağı ile bir taraftan yaşlı bireyler için tehlikeli bireylermiş gibi bir algı oluşturulurken; onların mobilizasyonu sınırlandırılarak yaşlı ayrımcılığına ortam oluşturulmuştur. Bu süreçte toplum tarafından belirli bir yaşın üzerindeki yaş grupları tek bir profil gibi konumlandırılarak sosyal ve kültürel farklılıklar ile cinsiyet gibi faktörler göz ardı edilmiştir. Bununla birlikte yaşlı bireylerin fiziksel ve duygusal ihtiyaçları arka plana atılarak diğer yaş grupları tarafindan onlar üzerinde hem açık hem de örtük bir tahakküm uygulanmıştır.

Foucault'ya göre tahakküm kurmanın tek yolu söylemler ve eylemler değildir. Söylemsel olmayan pratikler de tahakkümün kılcal damarlar gibi derinlere işlemesinde önemli bir araçtır 
(Layder, 2014: 143). Söylemsel olmayan pratikler, "söylemin tamamından ya da söylemin nesnelerinin tümünden bağımsız olarak var olan kurumlar, teknikler ve toplumsal formlar arasındaki ilişkiler"dir (Foucault, 1999: 63). Tahakküm söylemsel olan ve söylemsel olmayan pratikler arasındaki ilişkiler ağı etrafında kurulmaktadır. Özellikle sosyal medyada yaşı bireyler hakkında kullanılan olumsuz ifadeler ayrımcı tutum ve davranışları açık bir şekilde ortaya çıkarmıştır.

TÜIKK verilerine göre (2019) Türkiye'de her 5 haneden birinde en az bir yaşlının yaşadığı düşünüldüğünde uygulanan kısıtlamalarla birlikte kuşaklararası ilişkilerin de etkilendiğini söylemek yanlış olmayacaktır ${ }^{1}$. Yaşlı bireylere ayrımcı tavrılar hane içinde sıklıkla uygulanarak yaşlı bireylerin "iyi niyet" temelinde dahi olsa ayrımcılığa maruz kaldığı söylenebilmektedir. Söylemler ve söylemsel olmayan pratikler bireylerin birbirleri üzerinde mevkiler, katmanlar kurduğu alanlardır (Keskin, 1999: 18). Bu süreçte yaşlı bireylere yönelik keskin tavırlar sergilemek ya da yardıma muhtaç, düşkün gözüyle bakarak çocukla konuşur gibi söylemlerde bulunmak (sesi inceltmek, yüksek sesle konuşmak, beden dilini kullanarak anlatmaya çalışmak gibi) temelde ayrımcı bakış açısının işaretleridir.

Söylemsel ve söylemsel olmayan pratikler bazı şeylerin söylenmesine veya uygulanmasına imkân verirken bazı söylem ve davranışları da kısıtlamaktadır (Purvis \& Hunt, 2014: 21-22). Buradaki tahakküm söylen(e)meyenin ayyuka çıkmış şeklidir. COVID-19 sürecinde tehliklerle karş1 karşıya kalan yaşlı bireylerin maruz kaldıkları kısıtlamalar onların benlik saygısında azalmaya ve kimlik kaybına neden olmaktadır. Bu da başlı başına bir tahakküm göstergesi olarak yerini almaktadır.

\section{Sonuç ve Değerlendirme}

COVID-19 pandemisi küresel anlamda sosyal, kültürel ve ekonomik anlamda değişimi ve dönüşümü beraberinde getirdi. Virüsün tabiatı gereği en çok 65 yaş ve üstü bireyin sağlığını olumsuz etkilemesi, diğer yaş gruplarına nazaran en fazla 65 yaş üstü bireylerin bu virüs enfeksiyonundan dolayı yaşamını kaybetmesi, bu süreçte en dezavantajlı yaş grubunun 65 yaş üstü bireyler olmasına neden olmuştur. Kronik yaşa göre uygulanan sokağa çıkma kısıtlamaları nedeniyle yaşlı bireylerin uzun süre evde kalmaları, bir tahakküm alanına neden olarak kuşaklararası etkileşim süreçlerini de değiştirmiştir.

Pandeminin yol açmış olabileceği ölüm kaygısına ek olarak yaşlıların sosyal çevreleriyle etkileşimlerindeki değişim ya da dönüşüm yaşl1lık sürecinin seyrini de etkilemiştir. Öte yandan, yaşl1 bireylerin pandemi süreci deneyimleri, toplumsal konumlanışları, rolleri ve yaşam aranjmanları gibi pek çok etkene bağlıdır. Pandeminin kuşaklararası etkileşimde yarattığı dönüşüm yaşlı bireyin yalnız ya da aile fertleri ve/ya yakınları ile yaşayıp yaşamaması faktörü ile de şekillenmektedir. Yalnız yaşayan 65 yaş üstü bireyler pandemi sürecinde en basit ihtiyaçlarını karşılamak için dahi diğer bireylere muhtaç durumu gelmişlerdir. Aileleri ya da yakınları ile yaşayan 65 yaş üstü bireyler ise sokağa çıkma kısıtlamaları nedeniyle aynı hanede yaşadıkları bireylerle uzun günler geçirmek durumunda kalmıştır. Bu durum aile içindeki kuşaklararası etkileşimde değişime neden olarak ve kimi zaman kuşak çatışmalarına zemin hazırlamıştır.

$\mathrm{Bu}$ çalışmada önce farklı yaklaşımlarla yaşlı ayrımcılı̆̆ irdelendikten sonra yaşlı ayrımcılığının sacayağını oluşturan tahakküm, söylem ve iktidar kavramları Foucault ve Bourdieu sosyolojisine başvurarak pandemi döneminde yaşlıların değişen konumlanışı analiz edilmeye çalışılmıştır. Modernite sonrası tüketim toplumunda üretken olmadığı düşünülen yaşlı bireylerin pandemi süresince toplum ve aile fertleri tarafindan nasıl ötekileştirildiği tartışılmıştır. Arun ve

\footnotetext{
${ }^{1}$ Türkiye'de 2019 yılında toplam 24 milyon bin 940 haneden 5 milyon 629 bin 421'inde yaşlı nüfus olarak tanımlanan, 65 ve daha üzeri yaşta en az bir aile ferdi yaşamaktadır (TÜIKK, 2019). Daha detaylı bilgi için: http://www.tuik.gov.tr/PreHaberBultenleri.do?id=33712 .
} 
Elmas (2016: 360)'a göre “yaş Bourdieu'cu analizlerde oldukça geride kalan bir faktör olarak olagelmiştir". Ancak yine de yaşl1lığın yaş alma sürecinde habitus temelindeki yeniden üretimi, tahakküm ve söylem ile birlikte harmanlandığında yaşlı bireyin toplumdaki yerini okunabilir kılmıştır.

\section{Kaynakça}

Anadolu Ajans1, (2020). Türkiye'nin Koronavirüsle Mücadelesinde Son 24 Saatte Yaşananlar. https://www.aa.com.tr/tr/koronavirus/turkiyenin-koronavirusle-mucadelesinde-son-24saatte-yasananlar/1867101.

Arun, Ö. \& Elmas, Ç. (2016). Yaşl11ıkta ayrım: çağdaş Türkiye'de yerel yönetimleri bekleyen zorluklar. Sosyoloji Dergisi, 36, 351-372.

Abumere F.A. (2019). A political conception of pandemics and epidemics in Africa. G. B. Tangwa, A. Abayomi, S. Ujewe \& N. Munung (Eds). Socio-cultural Dimensions of Emerging Infectious Diseases in Africa (ss. 125-134). Springer.

Auzan, A. A. (2020). The economy under the pandemic and afterwards. Population and Economics 4(2), 4-12. https://dx.doi.org/10.3897/popecon.4.e53403

Ayalon, L. \& Tesch-Römer, C. (2018). Contemporary perspectives on ageism. L. Ayalon \& C. Tesch-Römer (Eds.), Introduction to the Section: Ageism-Concept and Origins (ss. 1-10). Springer Open.

Barth, L. (2008). Michel Foucault. R. Stones (Eds.) Sosyolojide İz Bırakanlar (ss. 298-312). Bağlam Yayınları.

Bond, J., Peace, S., Dittmann-Kohli, F. \& Westerhof, G. (2007). The ageing world. J. B. S. Peace, F. Dittmann-Kohli \& G. Westerhof (Eds.) Ageing in Society (3. Basım, ss. 1-14). Sage Publications.

Bourdieu, P. (1990). The logic of practice. Polity Press.

Bourdieu, P. (2000). Pascalian meditations. Polity.

Bourdieu, P. \& Wacquant, L. J. (2003). Düşünümsel bir antropoloji için cevaplar, (Çev. Nazlı Ökten). İletişim Yayınları.

Bourdieu, P. (2015). Ayrım: beğeni yargısının toplumsal eleştirisi. Heretik.

Butler, R. (1969). Age-Ism: Another form of bigotry. The Gerontologist, 9(4), 243-246. http://dx.doi.org/10.1093/geront/9.4_part_1.243

Bytheway, B. (1995). Rethinking ageing: Ageism. Open University Press.

Bytheway, B. (2005). Ageism and age categorization. Journal of Social Issues 61, 361-374. https://dx.doi.org/10.1111/j.1540-4560.2005.00410.x

Cary L.A, Chasteen AL \& Remedios J. (2017). The Ambivalent ageism scale: developing and validating a scale to measure benevolent and hostile ageism. The Gerontologist, 57(2), $27-$ 36. https://dx.doi.org/10.1093/geront/gnw118

Choonara, J. (2020). Socialism in a time of pandemics. International Socialism (2), 3-35.

Çevik M., Bamford C. G. G. \& Ho A. (2020). COVID-19 pandemic-a focused review for clinicians. Clinical Microbiology and Infection 81(5), 1-6. https://dx.doi.org/10.1016/j.cmi.2020.04.023 
Canatan, A. (2008). Toplumsal değerler ve yaşlılar. Yaş̧ı Sorunları Araştırma Dergisi (1), 62-71. https://dergipark.org.tr/en/pub/yasad/issue/21799/234272

Dean, M. (2009). How social age Trumped. D. Malcolm \& P. Cann, (Eds.), Unequal Ageing The Untold Story of Exclusion in Old Age (1-23). The Policy Press.

Dumas, A. \& Turner, B. S. (2006). Age and aging: the social world of Foucault and Bourdieu. J. S. Powell \& A. Wahidin (Eds.), Foucault and Aging (ss. 145-156). Nova Science Publishers.

Foucault, M. (1992). Hapishanenin doğuşu, (Çev. Mehmet Ali Kılıçbay). İmge Kitabevi.

Foucault, M. (1993). Ders özetleri (1970-1982), (Çev. Selahattin Hilav). Yapı Kredi Yayınları.

Foucault, M. (1999). Bilginin arkeolojisi, (Çev. Veli Urhan). Birey Yayınc1lı.

Foucault, M. (2001). Kelimeler ve şeyler: insan bilimlerinin bir arkeolojisi. (Çev. Mehmet Ali Kılıçbay). İmge Yayınları.

Foucault, M. (2016). Entelektüelin siyasi işlevi: seçme yazılar: 1, (Çev. Ferda Keskin ve Iş1k Ergüden). Ayrıntı Yayınları.

Forlenzaa, S., Bourassa, D., Lyman, M. \& Coughlin, M. (2019). Ageism, priming and working with older adults among undergraduate exercise science students. Physical \& Occupational Therapy In Geriatrics, 37(1), 50-66. https://dx.doi.org/10.1080/02703181.2019.1611691.

İçişleri Bakanlığı (2020). 65 Yaş ve Üstü ile Kronik Rahatsızlı̆̆ Olanlara Sokağa Çıkma Yasă̆ı Ek Genelgesi.

https://www.icisleri.gov.tr/65-yas-ve-ustu-ile-kronik-rahatsizligi-olanlara-sokaga-cikma-yasagi-ekgenelgesi.

Keskin, F. (1999). Söylem, arkeoloji ve iktidar. Doğu Batı Dergisi (9), 15-22. https://dergipark.org.tr/en/pub/kaygi/issue/27372/288052.

Layder, D (2006). Sosyal teoriye giriş, (Çev. Ümit Tatlıcan). Küre Yayınları.

Levy, B., Banaji, M.R., (2002). Implicit ageism. T. D. Nelson (Eds.) Ageism Streotyping and Prejudice Against Older Persons (ss. 49-75). Massachusetts Institute of Technology.

Maw, R. (2006). The AIDS pandemic: impact on science and society. Clinical Medicine Journal (6), 504-505. http://dx.doi.org/10.7861/clinmedicine.6-5-504a.

Mc Mullin, J. A., Marshall, V. W. (2001). Ageism, age relations and garment industry work in Montreal. The Gerontologist 41 (1), 111-122. https://dx.doi.org/10.1093/geront/41.1.111.

Megill, A. (2012). Aşırılı̆̆ın peygamberleri: Nietzsche, Heidegger, Foucault, Derrida, (Çev. Tuncay Birkan). Say Yayınları.

Özcan, H., Elkoca, A. \& Yalçı, Ö. (2020). COVID-19 enfeksiyonu ve gebelik üzerindeki etkileri. Anatolian Clinic the Journal of Medical Sciences, 25 (Supplement 1), 43-50. https://dx.doi.org/10.21673/anadoluklin.708151.

Palmore, E. B. (1999). Ageism, negative and positive (2. Basım). Springer Publishing Company.

Purvis, T. \& Hunt A. (2014). Söylem, ideoloji, söylem, ideoloji, söylem, ideoloji,... Moment Dergi, $1(1), 9-36$.

Sarup, M. (2004). Post-yapısalcılık ve post-modernizm (Çev. Abdülbaki Güçlü). Bilim ve Sanat Yay.

Singh, I., Chand, K., Singh, A. \& Kandadi, K. (2020). Time for a culture change: understanding and reducing risk, morbidity and mortality from COVID-19 in those of black and minority 


ethnicity. British Journal of Hospital Medicine (81), 1-4.
https://dx.doi.org/10.12968/hmed.2020.0241.

Spinney, L. (2019). How pandemics shape social evolution. Nature (574), 324-326. http://dx.doi.org/10.1038/d41586-019-03048-8.

Stephens, J. (2005). The AIDS pandemic: Impact on science and society. Emerging Infectious Diseases (11). 1807-1808. https://dx.doi.org/10.3201/eid1111.050897.

Sullivan, L. E. (drl). (2009). The Sage glossary of the social and behavioral sciences. Sage. http://dx.doi.org/10.4135/9781412972024.

Şahin, Y. (2017). Michel Foucault'da söylem analizi. Sosyal ve Kültürel Araştırmalar Dergisi (6), 119-135. https://dergipark.org.tr/en/pub/skad/issue/33118/368590

Tabish, S. A. (2020). COVID-19 pandemic: the crisis and the longer-term perspectives. Journal of Cardiology \& Current Research 13(2), 41-44. http://https://www.researchgate.net/deref/https\%3A\%2F\%2Fdoi.org\%2F10.15406\%2Fjccr. 2020.13.00472.

TÜİK (2018). Nüfus projeksiyonlart:2018-2080 http://www.tuik.gov.tr/PreHaberBultenleri.do?id=30567.

TÜIK (2019). Istatistiklerle yaşlılar. http://www.tuik.gov.tr/PreHaberBultenleri.do;jsessionid=GWwBpvbc4BtFxhFfhF3jhvyg3 plnSPYvnBBnVPfL22phJJZ4WH8v!1326336575?id=33712.

Vago, S. (2003). Social change (5. Baskl). Prentice Hall.

White, K. \& Banda, M. (2009). The role of civil society in pandemic preparedness. Andrew F. Cooper (Eds.), Innovation in Global Health Governance: Critical Cases (ss. 105-127). Taylor \& Francis Group.

WHO (2020a). WHO characterizes COVID-19 as a pandemic. https://www.who.int/emergencies/diseases/novel-coronavirus-2019/events-as-they-happen

WHO (2020b) Ageing and life course. https://www.who.int/ageing/ageism/en/.

Zachreson, C., Kristopher M. F.,Cliff, O. M., Harding, N., Piraveenan, M. \& Prokopenko, M. (2018). Urbanization affects peak timing, prevalence, and bimodality of influenza pandemics in Australia: Results of a census-calibrated model. Science Advances (4)12, 1-8. http://dx.doi.org/10.1126/sciadv.aau5294 